Portland State University

PDXScholar

7-10-1995

\title{
An Assessment of the Impact of Intimate Victim- Offender Relationship on Sentencing in Serious Assault Cases
}

Laura J. Hickman

Portland State University

Follow this and additional works at: https://pdxscholar.library.pdx.edu/open_access_etds

Part of the Criminology and Criminal Justice Commons Let us know how access to this document benefits you.

Recommended Citation

Hickman, Laura J., "An Assessment of the Impact of Intimate Victim-Offender Relationship on Sentencing in Serious Assault Cases" (1995). Dissertations and Theses. Paper 5059.

https://doi.org/10.15760/etd.6935

This Thesis is brought to you for free and open access. It has been accepted for inclusion in Dissertations and Theses by an authorized administrator of PDXScholar. Please contact us if we can make this document more accessible: pdxscholar@pdx.edu. 


\section{THESIS APPROVAL}

The abstract and thesis of Laura J. Hickman for the Master of Science in Administration of Justice were presented July 10,1995 , and accepted by the thesis committee and the department.

COMMITTEE APPROVALS:

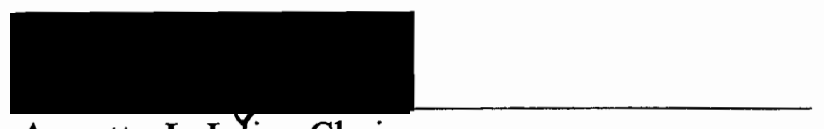

Annette I. Jolin, Chair
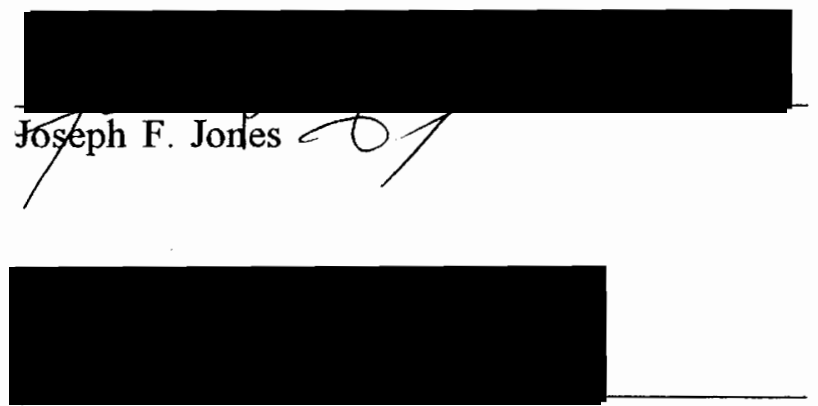

David K. Blanchard

DEPARTMENT APPROVAL:

Robert W. Lockwood, Chair

Kathryn A. Farr

Representative of the Office of Graduate Studies

Administration of Justice

by

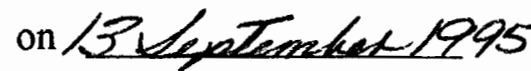




\begin{abstract}
An abstract of the thesis of Laura J. Hickman for the Master of Science in Administration of Justice presented July 10, 1995.
\end{abstract}

Title: An Assessment of the Impact of Intimate Victim-Offender Relationship on Sentencing in Serious Assault Cases.

It is generally agreed that a criminal justice system reflects the values of the society within which it exists. The presence of patriarchal social values will likely affect the response of the criminal justice system to intimate violence. While the perpetration of violence against another is a violation of an important social norm, patriarchal values may function to discount the seriousness of such an act, if the violence is perpetrated by a man against his girlfriend or wife. This discount of seriousness may lead to less severe punishment for men who assault their intimates than to men who assault nonintimates.

The purpose of the present study was to test the hypothesis that men who are convicted of committing serious assaults against female intimates receive more lenient punishment than men who are convicted of committing serious assault against nonintimates. Punishment was defined as sentencing outcomes, i. e. type and length of sentence. The sentences of offenders convicted of felony assaults as the major offense and subject to sentencing guidelines in Oregon in 1993 were examined. 
Chi-square tests were used to compare the sentence types of intimate and nonintimate violence offenders. Two-tailed t-tests and multiple linear regression were used to examine the relationship between victim-offender relationship and length of sentence. It appears that the presence of Oregon's sentencing guidelines, rather than victim-offender relationship, had the greatest effect upon the severity of punishment. This finding suggests that the guidelines may be responsible for minimizing the impact of patriarchal values on sentencing decisions in serious assault cases. 
AN ASSESSMENT OF THE IMPACT OF INTIMATE

VICTIM-OFFENDER RELATIONSHIP

ON SENTENCING IN SERIOUS ASSAULT CASES

by

LAURA J. HICKMAN

A thesis submitted in partial fulfillment of the requirements for the degree of

MASTER OF SCIENCE

in

ADMINISTRATION OF JUSTICE

Portland State University

1995 


\section{ACKNOWLEDGEMENTS}

I would like to thank the members of my thesis committee for their time, effort and concern.

To Dr. Annette Jolin, the chair of my committee, I owe a special debt of gratitude. Not only did she encourage, support, challenge and inspire me; she befriended me. My admiration is small return for the lifelong lessons I have learned under her tutorage. Dr. Jolin is truly one of my heroes. I only hope that I can reward her investment in me by working to make the world a safer place for women.

To Dr. Joseph Jones, I extend my thanks for his assistance, sense of humor and insistence on quality. I have benefitted immeasurably from his thorough reviews of my work and his efforts to "push me from the nest." It is because of Dr. Jones that I came to see myself as capable of greater things. I sincerely thank him for expanding my realm of possibilities.

To Dr. David Blanchard, I wish to give my thanks for the many ways he assisted me with this project. He gave me much of his valuable time, expertise and understanding. Dr. Blanchard's self-sacrifice, patient instruction and continual reassurance not only prevented several crises but "talked me down from the ledge" during several others.

To Dr. Kathy Farr, the graduate office representative on my committee, I offer my thanks for making the time to review my work on short notice and for offering her insightful comments and advise.

I would also like to thank Stephen Amos for his efforts in opening 
the door for this project at the Oregon Department of Corrections. I am also indebted to many Department of Corrections employees for their time and their help: Sally Anderson, Dawn Bruce, Shay Christenson, Larry Daniels, John Grill, Tamara Holden, Randy Ireson, Vickie Ross, Barbara Wells and numerous community corrections and correctional institution personnel.

I thank my family for their support and for their love. The encouragement of my parents and their great faith in me helped me weather many storms. Their sense of humor and wisdom assisted me in keeping my perspective and my sanity.

To my Raymond, I can only say thanks for his unending patience, understanding and, most of all, for listening. 


\section{TABLE OF CONTENTS}

LIST OF TABLES $\ldots \ldots \ldots \ldots \ldots \ldots \ldots \ldots \ldots \ldots \ldots \ldots$ ii

\section{CHAPTER}

I. INTRODUCTION $\ldots \ldots \ldots \ldots \ldots \ldots \ldots \ldots \ldots \ldots$

II. THE LITERATURE $\ldots \ldots \ldots \ldots \ldots \ldots \ldots \ldots \ldots$

III. MAJOR THEORETICAL PERSPECTIVES . . . . . . . . . 8

Theoretical Approach of the Present Study ........ 9

The Research Question .............. 14

Hypotheses ................ 15

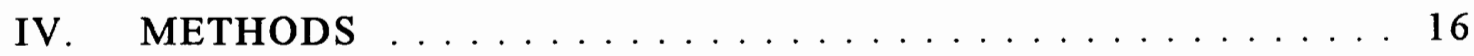

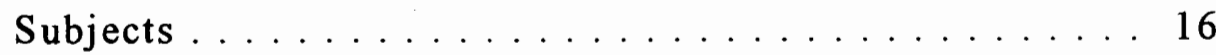

Data Sources .................. 16

The Independent Variable: Victim-offender relationship ............... 17

Dependent Variables: Sentencing Outcomes ..... 18

Procedures . . . . . . . . . . . . . . . . . 26

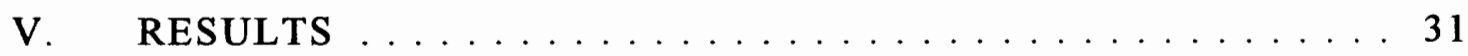

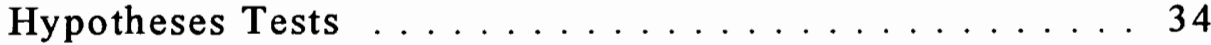

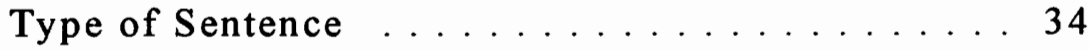

Length of Sentence ............... 35

Number of Custody Units and Jail Days ... . . . 37

Use of Optional Probation . . . . . . . . . 38

Gun Minimum Sentence ............. 39

Direction and Type of Sentencing Guidelines

Departure ............... 40

Length of Durational Departures . . . . . . . 43

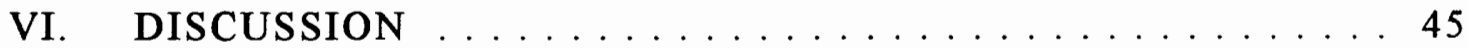

Summary of Results ............... 45

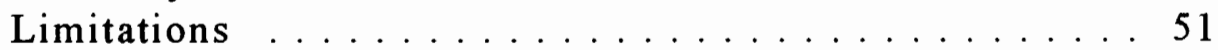

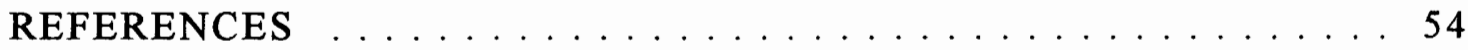

APPENDIX A: Criminal History Categories ...........61

APPENDIX B: Sentencing Guidelines Grid . . . . . . . . . 62

APPENDIX C: Mitigating and Aggravating Factors . . . . . . 63 
APPENDIX D: Sentencing Guidelines Worksheet .......... 64

APPENDIX E: Dichotomous Variables Used in Regression

Analyses ...................... 66

APPENDIX F: Criminal History Categories of

Intimate and Nonintimate Violence Offenders $\ldots \ldots \ldots 67$

APPENDIX G: Regression Tables: Length of Probation and Prison . . 68

APPENDIX H: Regression Tables: Number of Custody Units and

Jail Days . . . . . . . . . . . . . . . . . . . 69 


\section{LIST OF TABLES}

\section{TABLE}

1. Racial Distribution of Intimate and Nonintimate

Violence Offenders . . . . . . . . . . . . . . . 32

2. Intimate and Nonintimate Violence Offenders By

Most Serious Crime of Conviction ............. 33

3. Intimate and Nonintimate By Sentence Type Given and Presumptive Sentence Type ............. 35

4. Type and Length of Sentence of Intimate and Nonintimate Violence Offenders . . . . . . . . . . 37

5. Intimate and Nonintimate Violence Offenders

By Direction and Type of Guidelines Departure . . . . . . 43 


\section{CHAPTER I}

\section{INTRODUCTION}

Crime is a product of social values and norms. Society, guided by its values, create rules, or norms, by which individual members are to live. Some norms are considered to be so important to the welfare of society that violations of these rules are defined as crimes. In some instances, violation of important social rules are excused because they uphold social values of a higher order. For example, in American society, homicide is a crime, unless the murderer acted in self-defense. In this case, the social value placed upon the right to protect one's own life outweighs the social prohibition against murder. Violations of social rules that are defined as crimes are discouraged partially by the threat of punishment. The severity of the punishment typically depends upon the importance of the social norm that was violated and the social values relevant to the particular situation (Eitzen \& Zinn, 1988). For example, a transient who commits a crime by selling illegal drugs may be seen as deserving of more severe punishment if he or she sells drugs to children than if he or she sells drugs to other transients. The same norm has been violated in both cases. The latter crime, however, may be seen as a more serious threat to the welfare of society and deserving of more severe punishment because the violation also conflicts with the high social value placed upon the protection of children. 
Violent assaults are seen as a serious threat to the welfare of society and, thus, are defined as criminal behavior and deserving of punishment. Violent assaults may be seen as more or less of a social threat, depending upon the relevance of important social values in individual situations. The present study sought to uncover the effect of patriarchal values on the severity of punishment given to individuals who commit serious assaults. Specifically, the present study examined whether social values relating to victim-offender relationships influenced the severity of punishment for serious assault. 


\section{CHAPTER II \\ THE LITERATURE}

Social and legal tolerance of violence against female intimates is not unique to American society. The historical record clearly demonstrates that men have long treated women as their property (Martin, 1981; Brownmiller, 1975). Common law tradition, from which American law is derived, reflects the wife-as-property philosophy through the concept of coverture. Coverture dictates that marriage is a state that erases the legal identity of the wife and subjects her body and property to the unrelinquishable control and will of her husband (Marcus, 1994; Friedman, 1993; Elias, 1986; Szechtman, 1985; Martin, 1981). Common law, furthermore, explicitly permitted husbands to physically assault their wives, but prohibited beatings with a rod any thicker than the width of the man's thumb. American law tended to depart from this "rule of thumb" by allowing husbands to physically "discipline" their wives, but not to beat them (Marcus, 1994; Klein, 1982).

In her ground-breaking historical study of family violence in the United States, Pleck (1987) traced the evolution of the present socio-legal perspective on intimate violence against women.' Her work showed that the modern feminist movement was only one of three historic American

1 The term intimate violence is subsumed in the term domestic violence, but domestic violence refers to a group of intimate and familial relationships. Intimate violence is distinguished from domestic violence in that intimate violence occurs in the context of a romantic relationship and not within parent-child, sibling or other familial relationships (Fineman \& Mykitiuk, 1994; Pleck, 1987). 
social movements that brought about legal and social reform in the area of family violence. The first reform movement took place among the Puritans, of the Massachusetts Bay colony, in the mid-seventeenth century. These colonists were the first in the new world to pass laws prohibiting wife beating and child abuse. The second reform movement occurred during the late 19 th century and focused on criminalizing alcohol consumption. This movement championed abused women and children because they were viewed as victims of drunken husbands. The third reform movement surfaced in the mid-1970s, when battered women were "discovered" by twentieth century feminists reformers. This third movement, propelled by feminist, civil rights and law and order interests, brought about the most dramatic social and legal changes in the area of intimate violence against women. Largely as a result of these three social movements, physically assaulting wives is now a crime in most jurisdictions in the United States (Gordon, 1988; Pleck, 1987).

The mere passage of legislation prohibiting violence against women does not guarantee that laws are enforced nor does it ensure that intimate violence is seen as a serious social problem (Marcus, 1994; Buzawa \& Buzawa, 1993; Friedman, 1993; Pleck, 1987; Erez, 1986; Jolin, 1984). A body of literature addressing the issue of the criminal justice system's response (or lack thereof) to intimate violence has been slowly and steadily growing since the last great reform movement of the 1970 s. 
Police response to intimate violence has been an area of particular interest of researchers (Dunford, 1992; Jaffe, Wolfe, Telford \& Austin, 1986; Berk \& Newton, 1985; Sherman \& Berk, 1984).

The literature relating to the probability of arrest suggests that perpetrators of violent assaults on intimates, whether the victim is married to, cohabitating with or dating the assailant, are much less likely to be arrested than perpetrators of similar violence against nonintimate victims (Cohen, 1994; Buzawa \& Buzawa, 1993; McFerron, 1989; Pleck, 1987; Erez, 1986; Gondolf \& Worden \& Pollitz, 1984; Martin, 1981; Dobash \& Dobash, 1979; Parnas, 1967). In fact, incidents of intimate assault are frequently recorded and referred to by police as "domestic disturbances," a label that minimizes the seriousness of such assaults (Stanford \& Mowry, 1990; Erez, 1986; Breslin, 1978). When police do take action in intimate assault cases, arrests are most often made on misdemeanor charges, regardless of the severity of the injury to the victim, the assailant's injurious intent, or involvement of weapons (Buzawa \& Buzawa, 1993; Langan \& Innes, 1986; Edwards, 1985).

Public pressure and lawsuits brought against police departments that refused to arrest intimate assailants brought about some changes in police practices by the early 1980 s. But by far the greatest catalyst for radical change in arrest practices came from an initial research study conducted by Sherman and Berk (1984) in Minneapolis, in 1981. The findings of this 
experimentally designed study revealed that arresting intimate assaulters had a greater deterrent effect than other methods of police intervention, such as mediation and separation. In the wake of this study, numerous police polices and laws were enacted that support or mandate the arrest of intimate assaulters (Buzawa \& Buzawa, 1993; Gelles, 1993; Gondolf \& McFerron, 1989; Williams \& Hawkins, 1989).

The Minneapolis study (Sherman \& Berk, 1984) was followed by a series of replication studies in the cities of Omaha, Milwaukee, Charlotte, Metro-Dade County, Colorado Springs and Atlanta. The findings from these studies lent only partial support to the deterrent effect of arrest found by Sherman and Berk (1984). Because of methodological differences the original Minneapolis findings are not fully comparable to the multi-city studies. Still, the replication studies did call into question the suitability of arrest as the sole response to intimate violence. Arrest of intimate violence offenders in the cities of Omaha, Milwaukee and Charlotte seemed to increase their assaultive behavior, rather than to decrease it. This "backfiring" of arrest in these cities was most clearly associated with unemployment among the intimate assailants (Sherman, Schmidt \& Rogan, 1992). In addition to the Minneapolis study and the multi-city replication studies, other researchers have attempted to shed light on this issue (Dunford, 1992; Jaffe, Wolfe, Telford \& Austin, 1986; Berk \& Newton, 1985). To date it is not clear whether arrest deters 
intimate violence in general or if particular types of assaulters, such as the employed, are more likely to be discouraged from further assaults by arrest than are other types of intimate assaulters (Buzawa \& Buzawa, 1993).

While few studies exist that examine the response of prosecutors and courts to cases involving intimate violence, the available evidence consistently shows that prosecutors as well as the courts tend to treat intimate violence cases differently from stranger violence cases. Intimate assault cases at the prosecution and court level tend to be dismissed at a disproportionately high rate, downgraded to less serious offenses and regarded as needlessly consuming scarce resources (Hart, 1993; Ford, 1991; McGuire, 1991; Crowley, Sigler \& Johnson, 1990; Pleck, 1987;

Langan \& Innes, 1986; Lerman, 1986; Ellis, 1984; McLeod, 1983; Stanko, 1982; Davis \& Smith, 1981; Martin, 1981; Brosi, 1979; Vera Institute, 1977). There is little empirical information about the supervision of intimate violence offenders within the corrections component of the criminal justice system. 


\section{CHAPTER III}

\section{MAJOR THEORETICAL PERSPECTIVES}

Several theoretical perspectives currently dominate the literature regarding the etiology of, and social response to, intimate violence. Proponents of the psychological perspective view intimate assaults as the result of some pathology within the individual offender and/or victim (see for example, Roy, 1977). Studies of intimate violence originating from this perspective seek to uncover perpetrator and/or victim personality characteristics, childhood experiences, level of social skill development and the like, to explain the presence of violence within intimate relationships. Sociological perspectives cite structural factors within society as the causes of violence against intimates (Yllo, 1988). Research conducted under the sociological umbrella examines intimate violence in the context of social class, race, gender and family systems (see for example, Gelles, 1979). Feminist perspectives tend to view patriarchal, or male-dominated, social organizations and gender arrangements as the sources of intimate violence. ${ }^{2}$ They assert that there is a clear distinction between male-perpetrated and female-perpetrated intimate violence. Intimate violence against women is seen as a much larger and more pressing social problem than female violence against male intimates because male violence against females is a "normal" part of a patriarchal

2 A patriarchy is a societal structure that institutionalizes male control of women, both within intimate relationships and within the larger society (Lerner, 1986). 
society. Feminist-oriented studies of violence against women focus on gender inequality, social power and the functional utility of intimate violence within a society (see Yllo \& Bograd, 1988).

\section{Theoretical Approach of the Present Study}

The present study examines intimate violence from a feminist perspective. There are several forms of feminist theory, most of which share as a central concern the subordination of women. ${ }^{3}$ Each theory provides different explanations for this subordination and proposes different methods for ending it (Ollenburger \& Moore, 1991). In her discussion of the application of feminist theory to crime, Simpson (1989) outlines the three dominant theories - liberal, socialist and radical feminism. Liberal feminism views the subordination of women as the result of a lack of equal opportunity for women within society. Women are disadvantaged by traditional social roles that separate men from women and foster discrimination against women who seek to enter the "man's world." Liberal feminists assert that the subordination of women

3 According to Lerner (1986), the term "subordination" is a better description of gender relations within a patriarchal society than the commonly used term "oppression." Subordination implies a lower relative social position, but also that women may submit willingly to an inferior social position to men for purposes of survival and gaining advantages within the society, such as male protection. Oppression implies "forceful subordination"of women. While this term adequately describes the act of beating a woman into submission to male authority, this oppression occurs within a social structure of male domination and female subordination. Thus, subordination is a broader term that applies to gender relations in general and in the context of intimate relationships. 
can be eliminated by creating opportunities for women within society and ending discrimination against them, while breaking down traditional gender roles and stereotypes. Differential treatment of intimate violence offenders by the criminal justice system is viewed by liberal feminists as a result of inequities within the system. Strategies to produce more equitable treatment of all offenders, such as sentencing guidelines, are seen as important to the removal of discrimination toward intimate violence offenders from the criminal justice system.

Socialist feminism blames the subordination of women on economic systems. Capitalism and the ownership of private property have placed white men in powerful positions of control over the labor of all women and many men. Recreating economic systems and eliminating social classes are seen as solutions to gender subordination (Ollenburger \& Moore, 1991; Simpson, 1989; Messerschmidt, 1986). Socialist feminists link the criminal justice system's treatment of intimate violence offenders to the lack of economic power of intimate violence victims. If female victims of intimate violence were economically empowered by a restructuring of existing economic systems, according to socialist feminists, the criminal justice system would respond to intimate violence offenders differently.

Radical feminism, like socialist feminism, views a social system, in this case, patriarchy, as the main source of the subordination of women. 
Unlike the socialist feminists, radical feminists claim that the subordination of women by men was the first and most basic of all forms of human subordination (Ollenburger \& Moore, 1991). Historically, patriarchy, a society structured around male-domination, was produced as a result of the biological "disadvantages" of being female, i.e. less physical strength and the dependency on others necessitated by pregnancy, giving birth and caring for small children. Female biological factors allowed men to gain and maintain control. Physical violence was one "natural" method for men to control women. Radical feminists cite patriarchal social structures as the source of the subordination of women and claim that these social structures must be changed, in order to end male domination of women in general and intimate violence in particular (Ollenburger \& Moore, 1991; Simpson, 1989).

Radical feminist theory is particularly useful in explaining the phenomenon of intimate violence because of its explicit focus on male use of violence to control women (Martin, 1981; Dobash \& Dobash, 1979). Partly as a consequence of the male strength advantage and the forced dependence of women on men during the child-bearing years, males used violence and/or the threat of violence to gain and maintain control over females. The intimate relationship is merely a microcosm of the larger society, where men use violence and the threat of violence to subordinate and control women in a number of contexts. Within the domestic sphere, 
individual males have asserted ownership of individual females - their wives and daughters. Men are to assure that "their" women do not challenge the authority of male rule, both within the home and outside. It is within this context that the beating of women by their intimate partners takes place. Intimate violence becomes a tool used to terrorize women into submission to male authority, both collectively and individually (Rich, 1986; Dobash \& Dobash, 1979).

It is generally agreed that criminal justice systems reflect the values of the society within which they exists (Anderson \& Newman, 1993; Friedman, 1993). The presence of patriarchal social values is therefore likely to affect the response of the criminal justice system to intimate violence. While the use of violence against another violates an important social norm, patriarchal values may function to discount the seriousness of such violations, if the violence is perpetrated by a man against his woman (Beasley \& Thoman, 1994; Mahoney, 1994; Marcus, 1994; Rapaport, 1994; Romany, 1994; Schneider, 1994; Smart, 1989; Klein, 1982; Martin, 1981; Dobash \& Dobash, 1977/78, 1979; Brownmiller, 1975).

Until recently intimate violence was generally not considered to be crime. Today, mandatory arrest laws and other pro-arrest policies have largely ended the exemption of intimate violence from the social prohibition against violence. The redefining of intimate violence as crime implies that perpetrators of intimate violence deserve punishment. What 
is not clear, however, is whether intimate violence is punished as severely as nonintimate violence. The continued existence of patriarchal values may mean that intimate violence receives leniency where nonintimate violence does not. Therefore, a man who perpetrates violence against his woman may be punished less severely than a man who perpetrates violence against a man or a woman belonging to another man. ${ }^{4}$ Based upon these theoretical assertions, the present study sought to determine whether the criminal justice system punished men, who were convicted of serious assaults against intimates, less severely than men who assaulted nonintimates.

The impact of patriarchal values on the severity of punishment of intimate assaulters relative to nonintimate assaulters predicted by radical feminist theory may be lessened somewhat by Oregon's sentencing guidelines. The Oregon legislature, in 1989, voted to implement a set of standardized administrative rules for judges to follow when sentencing individuals for felony crimes. Standardized rules, or sentencing

4 This same line of reasoning explains why strangers who rape women receive more severe punishment than acquaintances who rape women (Estrich, 1987).

5 Radical feminist theory regards the dynamics involved in the criminal justice response to intimate violence by females against males as qualitatively different from the dynamics involved in the response to intimate violence by males against females. Gay and lesbian intimate violence also elicits a unique response from the criminal justice system (Rich, 1986). While the radical feminist perspective may be applied to the criminal justice processing of female-on-male and gay and lesbian intimate violence, it is beyond the scope of this study to develop several sets of theoretical propositions. 
guidelines, were seen as necessary because it appeared that unregulated judicial discretion often produced wide disparity in the severity of sentences given to individuals convicted of similar crimes (Bogan, 1990). One of the goals of Oregon's sentencing guidelines was to reduce the effects of extralegal factors on sentencing. The Oregon legislature wanted to create a set of rules that would produce similar sentences for similar crimes and criminals. To that end, the sentencing guidelines were implemented and are applicable to all felony crimes committed in the state of Oregon on or after November 1, 1989 (OCJC, 1989).

Despite standardized rules for sentencing offenders, some researchers have found that sentencing guidelines may not completely remove extralegal factors from sentencing decisions. Sentencing disparity based on extralegal factors such as race and socioeconomic status may still be present under sentencing guidelines rules (Miller, 1994; OCJC, 1994; Oregon Supreme Court Task Force, 1994; D'Alessio \& Stolzenberg, 1993). The use of sentencing guidelines in Oregon may lessen but not eliminate the impact of patriarchal values on sentencing in cases of serious intimate assault.

\section{The Research Question}

Do intimate violence offenders subject to sentencing guidelines and convicted of serious assaults in Oregon in 1993 receive more lenient punishment than nonintimate violence offenders under like circumstances? 


\section{Hypotheses}

The radical feminist perspective regarding the relative severity of punishment leads to the following hypotheses:

1. Intimate violence offenders are more likely than nonintimate violence offenders to receive a sentence type of probation rather than prison.

2. Intimate violence offenders receive shorter sentences than nonintimate violence offenders.

3. Intimate violence offenders are sentenced to fewer custody units and jail days than nonintimate violence offenders.

4. Eligible intimate violence offenders are more likely than are eligible nonintimate violence offenders to be given optional probation, instead of prison.

5. Intimate violence offenders who used firearms during the commission of the assault are less likely than nonintimate violence offenders to receive a gun minimum sentence.

6. When there are departures from presumptive sentences, both downward dispositional and downward durational departures are more likely to occur in the sentences of intimate violence offenders than in the sentences of nonintimate violence offenders.

7. Downward durational departures result in shorter sentences for intimate violence offenders than nonintimate violence offenders. 


\section{CHAPTER IV}

\section{METHODS}

\section{Subiects}

The population for this study is composed of male offenders who:

1. were convicted in Oregon of completed or attempted Assault I, II or completed Assault III as the major offense, 2. were subject to Oregon's sentencing guidelines and 3. had a conviction or sentencing date during the calendar year of 1993 . There were 476 offenders who met these criteria identified through the use of the Oregon Department of Corrections' automated database, known as the Offender Profile System (OPS) ${ }^{6,7}$

\section{Data Sources}

The data for this study came from six sources; OPS, Oregon Criminal Justice Council's (OCJC) sentencing guidelines database,

6 One nonintimate violence offender was excluded from the population because he was sentenced as a "dangerous offender." This type of offender is defined statutorily as suffering from "a severe personality disorder", under ORS. 161.737. The length of his sentence was more than eight standard deviations above the mean. Six offenders were excluded from the study because their assault convictions came as the result of attacks on inmates while they were incarcerated for other crimes. Of the offenders with a felony assault as the most serious conviction, during 1993, 18 were excluded from this study's population because they were not subject to sentencing guidelines, due to a crime commission date before November 1, 1989.

7 The Bureau of Justice Statistics reported that in 199112 percent of the male state prisoners serving sentences for assault nationwide had been convicted of assaulting an intimate (BJS, 1993). Based upon this finding and the lack of other information suggesting that the percent of intimate violence offenders within the defined population would be larger, a census rather than a sample was drawn from the defined population of offenders in order to ensure that enough intimate violence offenders were identified to allow tests of hypotheses. 
Assault III, ORS $163.185,163.175$, and $163.165 .^{10}$

\section{Dependent Variables: Sentencing_Outcomes}

For the purposes of this study, punishment is defined as sentencing outcomes. Sentencing outcomes are reflected in type and length of sentence and are derived from Oregon's sentencing guidelines. The Oregon Criminal Justice Council (OCJC) was created by the Oregon legislature for the purpose of developing and monitoring the implementation and functioning of the sentencing guidelines. The OCJC concluded that the two most relevant pieces of information in the determination of sentence severity ought to be 1 . the seriousness of the crime committed and 2 . the offender's criminal history. Seriousness was ranked from one to eleven, one being the least serious and eleven being the most serious. For example, the crime of bigamy was assigned a seriousness ranking of one, because it was perceived to be a relatively minor felony. The crime of murder was assigned a seriousness ranking of eleven, because it was viewed as a very serious felony. Attempted crimes received seriousness rankings two levels below those of completed crimes.

10 Attempted Assault III is not included here because this crime is statutorily defined as a misdemeanor. The narrow focus on felony assault crimes should not be understood as denial of the existence of intimate violence in many other forms of crime. For example, intimates are robbed, sexually assaulted, burglarized, kidnapped, stalked and murdered. Broadening the study to include these other types of crimes was not possible in this context, largely because Oregon's crime data did not identify intimate violence offenders. Limited resources prevented this broader focus. 
Murder was ranked as an eleven, so attempted murder was ranked as a nine. Criminal history was also grouped into categories, based upon the offenders' number and type of prior juvenile and adult convictions. The categories are alphabetic and range from the least serious, category I, to the most serious category A. Prior convictions for crimes against people, such as robbery, were considered to be more serious than convictions for crimes against property, such as theft (see Appendix A for contents of the criminal history categories).

By placing the values representing crime seriousness on the $\mathrm{Y}$-axis and the alphabetical categories representing criminal history on the $\mathrm{X}$ axis, the OCJC created a sentencing grid. The grid prescribes sentence type, i. e. probation or prison, and sentence length for each grid block. Individual offenders are sentenced to the type and length of sentence specified within the grid block that is at the intersection of each offender's criminal history and crime seriousness scores (see Appendix B for the sentencing guidelines grid). The resulting sentence is the presumptive sentence. Presumptive prison sentences specify length of sentence in a range of months. Judges may sentence offenders to a number of months within that range. Presumptive sentences of prison also carry presumptive terms of post-prison supervision (OCJC, 1989). ${ }^{11}$

11 Parole officers were renamed post-prison supervision officers, but continue to supervise those offenders still on parole under the old system. 
Presumptive probation sentences consist of a pre-determined length in months and a maximum number of custody units. Custody units may include jail and various other forms of intermediate sanctions, such as house arrest and mandatory in-patient drug treatment. For example, grid block 6-G prescribes a presumptive sentence of probation and a maximum of 180 custody units (see Appendix B for the sentencing guidelines grid). This means that the offender may be sentenced to a maximum of 90 days in jail. The remaining 90 custody units may be used to sentence the offender to other forms of custody, such as in-patient substance abuse treatment. Presumptive probation sentences provide only the maximum number of custody units and jail days to which judges may sentence offenders. Judges have the option of sentencing offenders to no custody units or jail days. In other words, presumptive probation sentences may result in a specified number of months of probation and nothing more (OCJC, 1994).

The OCJC anticipated that occasionally circumstances of the crime or characteristics of the offender would make the presumptive sentence prescribed by the guidelines inappropriate. For example, an offender may be seen as deserving of a less severe sentence than the one prescribed under the guidelines if he or she suffers from a mental illness. In cases like these, judges may sentence offenders to a different type of sentence or length of sentence, if they cite "substantial and compelling reasons" why 
the presumptive guidelines sentence is not appropriate for a particular offender (OCJC, 1989). The "substantial and compelling reasons" under the guidelines are called mitigating and aggravating factors. Mitigating factors are reasons why particular offenders ought to be given a more lenient sentence than the sentence prescribed by the guidelines.

Aggravating factors are reasons why particular offenders ought to be given a more severe sentence than the sentence prescribed by the guidelines (see Appendix $\mathrm{C}$ for a list of the mitigating and aggravating factors).

A sentence of a different type or length than the sentence prescribed by the guidelines is called a departure. If a judge sentences an offender to probation, when the presumptive sentence calls for prison, or gives an offender a shorter sentence than the one provided by the guidelines, this is called a downward departure. The judge must cite at least one of the nine mitigating factors to explain why she or he felt that the departure from the guidelines was warranted. If a judge gives a sentences that exceeds the presumptive sentence in type of length, this is called an upward departure. The judge must then cite at least one of the twelve aggravating factors as justification for the departure (OCJC, 1994).

A few grid blocks within the guidelines prescribe a presumptive sentence of prison, but judges have the option of sentencing offenders to probation, without departing from the guidelines, if certain conditions are met. Offenders within the grid blocks 8-G, 8-H or 8-I, may be sentenced 
to probation, instead of prison, if they 1 . did not use a firearm in the commission of their offense, 2 . were not under bench or correctional supervision at the time of the offense and 3. are able to participate in treatment. Offenders who satisfy these conditions are referred to as "eligible for optional probation" (OCJC, 1994).

In order to assist the OCJC in monitoring the functioning of sentencing guidelines, Oregon law (ORS 137.010) requires that all courts submit a sentencing guideline worksheet containing sentencing information for each felony conviction to various criminal justice agencies, including the Department of Corrections and the OCJC. The sentencing guidelines worksheets are intended to provide a simplified format for judges to use to determine and report individual offender's presumptive sentences based on the sentencing grid and to justify departures from that grid (see Appendix D for worksheet). The OCJC collects these worksheets and enters the information in the existing sentencing guidelines database. The OCJC uses the information from this database to produce an annual report that summarizes sentencing practices in Oregon. ${ }^{12}$

12 When errors are discovered or when worksheets are not filled out completely, the OCJC contacts the sentencing court, in order to request correction of the error(s) and/or more information. Through this quality control process, the OCJC found that ten percent of the reports that it received in 1993 contained some type of error, either in calculation of the crime seriousness ranking or the criminal history classification, missing data, an improper sentence imposed or guidelines departure error. These errors were corrected by the sentencing court in 27 percent 
In the present study, sentencing outcomes took the form of number of custody units, number of jail days, use of gun minimum sentences, use of optional probation and type, direction and length of sentencing guidelines departure ordered by the sentencing judge as a result of the most serious assault conviction. Sentencing outcome variables were coded as follows:

Type of sentence was defined as either prison or probation. ${ }^{13}$

Length of sentence was recorded in months.

Number of custody units applied only to probationers.

Number of jail days applied only to probationers.

Use of gun minimum was recorded if the judge imposed a gun minimum sentence as a result of the offender's firearm use during the commission of the assault. Oregon law (ORS 161.610) states that offenders who use a gun in the commission of an offense shall be given a mandatory sentence of 60 months. If the presumptive guidelines sentence is longer than 60 months, the judge is directed to give the offender the longer presumptive sentence. Judges may reduce the length of a gun minimum sentence by citing mitigating factors (OCJC, 1994).

of the cases, thus reducing the overall error in the sentencing guidelines worksheets entered in the database to approximately eight percent (OCJC, 1994). There is no reason to expect that this error is systematic or that it will disproportionately affect sentences for the crime of assault.

13 Probation sentences include those offenders who were sentenced to optional probation. 
Use of optional probation applied only to the sentencing of offenders who 1. fell into grid blocks 8-G, 8-H and 8-I, 2. were not under correctional supervision at the time of the assault, 3 . did not use a firearm in the commission of the crime and 4 . were amenable to treatment. Whether or not eligible offenders were sentenced to optional probation, instead of prison, was recorded.

Type of guidelines departure had two attributes. The first applied to dispositional departures, which are sentence types that depart from the guidelines, such as probation instead of prison. The second attribute, durational departures, referred to sentences of a different length than is prescribed by the guidelines.

Direction of departure reflected whether the imposed sentence was more or less severe than the sentence that the guidelines provided. Increased severity may mean sentences of greater length or more restrictive sentencing type, e.g. number of jail days, number of custody units and/or upgraded supervision status from probation to prison. Direction of departure was coded as either upward (increased severity of sentence) or downward (decreased severity of sentence).

Length of Durational Departure was measured in one of two ways. In the case of an upward durational departure, length of departure was calculated by subtracting the maximum presumptive sentence length from the actual sentence length. If the departure was downward, length of departure was 
determined by subtracting the minimum presumptive sentence from the ordered sentence. ${ }^{14}$

The following variables were used as controls, i.e. variable besides victim-offender relationship that may affect sentencing outcomes: Crime of conviction was either completed or attempted Assault I, II or completed Assault III.

Seriousness ranking of the offense may only vary in completed or attempted Assault I convictions, the other assault offenses have been preassigned seriousness rankings. ${ }^{15}$ Completed Assault I received a seriousness ranking of ten, but was reduced to a ranking of nine if the "victim(s) substantially contributed to the commission of the offense by precipitating attack" (ORS 163.185). Attempted Assault I receives a seriousness ranking of eight, but was reduced to a ranking of seven under the same victim precipitation rule (OCJC, 1994).

14 For example, if an offender fells into guidelines grid block 8-D, her or his presumptive sentence ranges from 27 to 28 months in prison. If the judge ordered an upward durational departure to 30 months, instead of the maximum 28 months, the length of the departure would equal two months. If that same offender were given a downward durational departure to 25 months, the length of the durational departure would be negative two months.

15 Completed and attempted Assault II convictions and completed Assault III convictions are preassigned seriousness rankings. Completed Assault II receives a ranking of eight, while both Attempted Assault II and completed Assault III receive a seriousness ranking of six. 
Supervision status at the time of the commission of the assault was of three types: 1. no supervision, 2. probation, and 3. post-prison/parole. ${ }^{16}$ Offender use of a firearm was recorded if the offender used a firearm during the commission of the assault.

Criminal history classification, ranging from $A$ to $I$, was based on prior criminal convictions and determined the offenders' location along the $\mathrm{X}$ axis of the sentencing guidelines grid (see Appendix A).

\section{Procedures $^{17}$}

Sentencing outcome data came largely from the OCJC guidelines automated database. The information was coded in the same manner that it was coded on the sentencing guidelines worksheet and in the sentencing guidelines database. ${ }^{18}$ When missing data were encountered within the OCJC database, the OPS, offender institution files, offender supervision field files, probation officers and institution counselors were consulted to acquire the needed information.

Information on the independent variable, victim-offender relationship, was not recorded in the OCJC database. Police reports,

${ }^{16}$ If an offender was under both probation and post-prison/parole supervision at the time of the assault, the offender was coded by the more restrictive type of supervision, i. e. post-prison/parole.

17 These procedures were proposed to the Human Subjects Research Review Committee which considered them to be exempt from Human Subjects review.

18 Inter-coder reliability is not discussed in the present study because this author personally conducted all data collection and coding. 
presentence investigation reports, institution counselor narratives, supervision chronologies, probation and parole/post-prison supervision violation reports, court documents and treatment reports were searched for intimate relationship indicators, $i$. e. the description of the victim as a present or former girlfriend or wife. If one or more of these documents referred to the victim of the most serious assault as the offender's present or former girlfriend or wife, the offender was categorized as an intimate violence offender. If the victim was described as anyone other than a present or former girlfriend or wife, the offender was categorized as a nonintimate violence offender. ${ }^{19}$

Presentence investigation reports, which offer a detailed description of the crime, the circumstances surrounding it, and the victim-offender relationship, were sometimes available through the OPS. Victim-offender relationship was determined through the use of the OPS in approximately 20 percent of the cases. In the remaining cases, offender institution files and offender supervision field files were reviewed to determine victim-

${ }^{19}$ Relying on many different criminal justice actors to define victim-offender relationship may be considered problematic in that the definition of terms may not be consistent. Inconsistency in the operationalization of the independent variable is a threat to the reliability and validity of the study's findings. This threat is reduced because of the general social agreement regarding the definition of an intimate relationship. The terms girlfriend and wife are generally defined in American culture as involving commitment, emotional and sexual intimacy and particular role responsibilities (Carlson, 1987). Criminal justice actors, such as police, prosecutors, judges and corrections personnel, respond to intimate violence in the context of their individual perceptions of the definition of an intimate relationship and what rights and responsibilities that intimacy implies (Myers, 1989). 
offender relationship. ${ }^{20}$ When the institution and field files failed to provide the necessary information, individual probation and post-prison supervision officers and institution counselors were contacted. ${ }^{21}$ These individuals were able to provide victim-offender relationship information by either: 1. their personal knowledge of the specific details of the incident and/or victim, 2. contacting district attorneys' offices and requesting the information from prosecutorial files, 3 . requesting a copy of the original police report, or 4 . interviewing the offender. ${ }^{22}$

In the event that there was more than one serious assault conviction stemming from the same incident, the victim of the most serious assault conviction was used to determine victim-offender relationship. For example, if an offender were convicted of committing an Assault I against

${ }^{20}$ Offender institution files are created for those offenders who are sentenced to prison and are maintained within the particular correctional facility that houses the individual offenders. Each offender's institution file may contain all or some of the following documents: police reports, presentence investigation report, treatment reports, court documents, narrative provided by prison intake counselors, institution behavior reports and miscellaneous offender-specific materials, such as victim notification requests. For those offenders who receive a sentence of probation for their crime, field files are created and maintained within the county of the offender's supervision. Field files differ somewhat from institution files in that they contain chronologies of the offenders' behavior during the period of correctional supervision, and they lack intake counselor narrative and institution behavior reports.

21 Institution counselors and probation and parole/post-prison supervision officers were consulted in $58(10.7 \%)$ cases. Victim-offender relationship in six of the cases was obtained directly from the files of the Multnomah county district attorney's office.

${ }^{22}$ Victim-offender relationship was determined via offender interview in five cases. 
a neighbor and an Assault III against his wife as part of the same violent incident, the offender was defined as a nonintimate violence offender. ${ }^{23}$

Using the data-collection methods described above, victim-offender relationship could not be determined in eight, or .02 percent, of the cases. Due to the absence of information on the independent variable, these cases were removed from all analyses, thereby reducing the population to 468 offenders.

The five categorical measures of sentencing outcomes, type of sentence, type of guidelines departure, direction of guidelines departure, gun minimum sentence and use of optional probation, were analyzed through the use of chi-square tests. ${ }^{24}$ The continuous measures of sentencing outcome, length of sentence, length of duration departure, number of custody units and the number of jail days, were analyzed through the use of t-tests for independent samples and multiple linear

23 This situation very rarely arose among the defined population. In the event that an offender was convicted of two counts of the same type of serious assault, such as Assault II, the victim of the first count determined victim-offender relationship. For example, if an offender were convicted of two counts of Attempted Assault I and the victim listed in the first count was the ex-girlfriend of the assailant, that individual would have been recorded as an intimate violence offender. If, however, the victim listed in the first count were a nonintimate, the offender would have been counted as a nonintimate violence offender. No offenders were found to have been convicted of two counts of the same type of serious assault with both an intimate and a nonintimate listed as the victims, in any order.

24 While these are not analytically ideal levels of measurement, categorical data have been recognized as one typical feature of criminal case-processing research (Straus, 1993). 
regression. For purposes of regression analyses, several categorical variables were collapsed into dichotomous variables and included some measures of offender demographics (see Appendix E). ${ }^{25}$

25 Offender demographics, such as age, race and jurisdiction, may affect case processing (Miller, 1994; Oregon Criminal Justice Council, 1994; D'Alessio \& Stolzenbery, 1993; Crank, 1992; Albonetti, 1991; Chen, 1991; Erez \& Tontodonata, 1990; Mohr, 1990; Spohn, 1990; Schmidt \& Steury, 1989; Casper, 1988; Daly, 1987; Langan, 1985). Within several of the regression models, variables were included to control for the affects of offender demographics, such as race and county of conviction. 


\section{CHAPTER V}

\section{RESULTS}

Seventy (15\%) of the 468 offenders were intimate violence offenders, while $398(85 \%)$ were nonintimate violence offenders. The average age of the intimate violence offenders was 31.5 years and of the nonintimate violence offenders was 28.0 years. This difference in average age was statistically significant $\underline{t}(466)=2.85, p<.05$. The majority of intimate and nonintimate violence offenders were white. Thirty-nine $(55.7 \%)$ intimate violence offenders and $281(70.6 \%)$ nonintimate violence offenders were white. Most of the non white intimate violence offenders were African American, accounting for 30 percent of all intimate violence offenders and 13.1 percent of all nonintimate violence offenders (see Table 1). 


\section{Table 1}

Racial Distribution of Intimate and Nonintimate Violence Offenders

\begin{tabular}{||c|c|c|}
\hline Race & $\begin{array}{c}\text { Intimate } \\
\mathrm{N}=70\end{array}$ & $\begin{array}{c}\text { Nonintimate } \\
\mathrm{N}=398\end{array}$ \\
\hline White & $\begin{array}{c}39 \\
55.7 \%\end{array}$ & $\begin{array}{c}281 \\
70.6 \%\end{array}$ \\
\hline African & 21 & 52 \\
American & $30.0 \%$ & $13.1 \%$ \\
\hline Hispanic & 9 & 46 \\
& $12.9 \%$ & $11.6 \%$ \\
\hline Native & 0 & 10 \\
American & - & $2.5 \%$ \\
\hline Asian & 1 & 9 \\
\hline
\end{tabular}

Of intimate violence offenders, $41(58.6 \%)$ were convicted of either Assault III or Attempted Assault II and 229 (57.5\%) nonintimate violence offenders were convicted of one of these crimes. Twenty-nine intimate violence offenders ( $41.4 \%$ ) were convicted of one of the more legally serious forms of assault, Assault I, II or Attempted Assault I. One hundred sixty-nine (42.5\%) nonintimate violence offenders were convicted of one of these more serious forms of assault (see Table 2). There is a significant difference among the type of assault conviction of intimate and nonintimate violence offenders $x^{2}(9, \underline{N}=468)=38.0661, \underline{p}<.05$. The greatest difference appears to be in an under-representation of intimate violence offenders in the Assault III category and an over-representation of the same in the Attempted Assault II category. Of the seven intimate 
violence offenders convicted of Assault I and Attempted Assault I, three were seen by the judge or jury as having been provoked by a victim who "substantially precipitated" in the assault, as evidenced by the reduced seriousness ranking of the crime. Of the 53 nonintimate violence offenders convicted of the same crimes, $22(42 \%)$ were seen as similarly provoked by the assault victim.

\section{Table 2}

Intimate and Nonintimate Violence Offenders By Most Serious Crime of Conviction

\begin{tabular}{||c|c|c||}
\hline Crime & $\begin{array}{c}\text { Intimate } \\
\mathrm{N}=70\end{array}$ & $\begin{array}{c}\text { Nonintimate } \\
\mathrm{N}=398\end{array}$ \\
\hline Completed & 17 & 192 \\
Assault III & $24.3 \%$ & $48.2 \%$ \\
\hline Attempted & 24 & 37 \\
Assault II & $34.3 \%$ & $9.3 \%$ \\
\hline Completed & 22 & 110 \\
Assault II & $31.4 \%$ & $27.6 \%$ \\
\hline Attempted & 3 & 26 \\
Assault I & $4.3 \%$ & $5.6 \%$ \\
\hline Completed & 4 & 36 \\
Assault I & $5.7 \%$ & $9.0 \%$ \\
\hline
\end{tabular}

About sixty-seven percent of intimate violence offenders and 66.6 percent of nonintimate violence offenders, were grouped within the three least extensive criminal history categories, I, H and G (see Appendix F for a table of the criminal history categories of intimate and nonintimate violence offenders). About 30 percent of all offenders were under some 
form of correctional supervision at the time the assault was committed. Sixteen $(22.9 \%)$ intimate violence offenders were on probation at the time of the assault and six (8.6\%) were on parole or post-prison supervision. Eighty-six (21.6\%) nonintimate violence offenders were on probation at the time of the assault, while $33(8.3 \%)$ were on parole or post-prison supervision. ${ }^{26}$

\section{Hypotheses Tests}

Type of Sentence

Nearly identical percentages of intimate and nonintimate violence offenders were sentenced to probation and prison. Of intimate violence offenders, $43(61.4 \%)$ were sentenced to probation, while $246(61.8 \%)$ nonintimate violence offenders were sentenced to probation. Similarly, 27 (38.6\%) intimate violence offenders were sentenced to prison and 152 (38.2\%) nonintimate violence offenders were sentenced to prison (see Table 4). Overall, 15 percent of the offenders sentenced to prison were intimate violence offenders. This represents a slightly larger percentage of intimate violence offenders among those sentenced to prison for felony assault than the 12 percent found by the Bureau of Justice Statistics (1993) in its survey of male state prisoners. Of the 43 intimate violence offenders sentenced to probation, $15(34.9 \%)$ had a presumptive sentence

26 In the cases of two nonintimate violence offenders, supervision status at the time of the assault could not be determined. 
under the sentencing guidelines of prison. Of the 246 nonintimate violence offenders sentenced to probation, $66(26.8 \%)$ had a presumptive sentence of prison. One intimate violence offender and four nonintimate violence offenders had a presumptive sentence of probation, but were sentenced to prison (see Table 3 ). ${ }^{27}$

\section{Table 3}

Intimate and Nonintimate By Sentence Type Given and Presumptive Sentence Type*

\begin{tabular}{|c|c|c|}
\hline Type of Sentence & $\begin{array}{l}\text { Intimate } \\
N=70\end{array}$ & $\begin{array}{c}\text { Nonintimate } \\
\mathrm{N}=398\end{array}$ \\
\hline $\begin{array}{c}\text { Given Presumptive } \\
\text { Probation }\end{array}$ & $\begin{array}{c}28 \\
40.0 \%\end{array}$ & $\begin{array}{c}180 \\
45.2 \%\end{array}$ \\
\hline $\begin{array}{c}\text { Given Non- } \\
\text { Presumptive Probation }\end{array}$ & $\begin{array}{c}15 \\
21.4 \%\end{array}$ & $\begin{array}{c}66 \\
16.6 \%\end{array}$ \\
\hline $\begin{array}{c}\text { Given Presumptive } \\
\text { Prison }\end{array}$ & $\begin{array}{c}26 \\
37.1 \% \\
\end{array}$ & $\begin{array}{c}148 \\
37.2 \% \\
\end{array}$ \\
\hline $\begin{array}{c}\text { Given Non- } \\
\text { Presumptive Prison }\end{array}$ & $\begin{array}{l}1 \\
-\end{array}$ & $\begin{array}{l}4 \\
-\end{array}$ \\
\hline
\end{tabular}

* Columns do not add to $100 \%$ due to rounding

\section{Length of Sentence}

Length of sentence was examined by type of sentence, because probation and prison sentences are qualitatively different types of sentences. For those intimate violence offenders sentenced to probation,

27 A chi-square test could not be preformed on the differences in presumptive and given sentence type for intimate and nonintimate violence offenders due to the small numbers of intimate and nonintimate violence offenders in some cells. 
the average length of sentence was 35.4 months. The average length of sentence for nonintimate violence offenders sentenced to probation was 37.0 months. This difference in means is statistically significant $t(287)=$ $-2.76, p<.05$ (see Table 4). Length of probation sentence was regressed on a number of independent variables thought to be predictive of probation length; presumptive probation length, criminal history, guidelines departure, presumptive sentence type, type of crime, victim-offender relationship and supervision status. Victim-offender relationship was not significant when these other variables were taken into account. Variables found to significantly predict length of probation sentence were presumptive probation length and supervision status (see Appendix G).

Intimate violence offenders who were sentenced to prison received a mean sentence of 23.1 months and nonintimate violence offenders sentenced to prison received an average of 31 months. This difference in sentence length was not significant. Length of prison sentence was regressed on several variables; presumptive sentence type, minimum presumptive sentence length, type of crime, criminal history, victimoffender relationship and supervision status. Of these variables, the only one found to significantly predict length of prison sentence was minimum presumptive sentence length (see Appendix G). 


\section{$\underline{\text { Table } 4}$}

Type and Length of Sentence of Intimate and Nonintimate Violence Offenders

\begin{tabular}{||c|c|c||}
\hline Variable & $\begin{array}{c}\text { Intimate } \\
\mathrm{N}=70\end{array}$ & $\begin{array}{c}\text { Nonintimate } \\
\mathrm{N}=398\end{array}$ \\
\hline Sentence Type & $43(61.4 \%)$ & $246(61.8 \%)$ \\
\hline Probation & $27(38.6 \%)$ & $152(38.2 \%)$ \\
Prison & & \\
\hline Average & & 37.0 months \\
Sentence_Length & 35.4 months & 31.0 months \\
\hline Probation & 23.1 months \\
Prison &
\end{tabular}

\section{Number of Custody Units and Jail Days}

The mean number of custody units given to intimate violence offenders as a part of their probation sentences was 115 and to nonintimate violence offenders was 124 . This difference in means was not statistically significant. Custody units were regressed on a number of variables; criminal history, type of crime, supervision status, guidelines departure, presumptive sentence type, county of conviction, victimoffender relationship and racial minority. The variable that was found to be significant in predicting number of custody units offenders were sentenced to was the county of conviction (see Appendix H) ${ }^{28}$

Intimate violence offenders were sentenced to an average of 44

28 Multnomah county sentenced probationers to an average of 108 , while the other Oregon counties, in toto, sentenced probationers to an average of 132 custody units. This difference in means is statistically significant $\mathbf{t}(242)=-2.67, \mathfrak{p}<.05$. 
days in jail, while nonintimate violence offenders were sentenced to an average of 45 days. This difference is not statistically significant. One intimate violence offender was sentenced to serve 360 days in jail as part of his probation sentence, twice the number of jail days given to any other offender. ${ }^{29}$ Removing this offender from the group resulted in a reduction of the average number of jail days from 43 to 36 days. The removal of this extreme case does not produce a significant difference between the average number of jail days given to intimate and nonintimate violence offenders. Number of jail days was regressed on several independent variables; criminal history, type of crime, supervision status, guidelines departure, length of probation sentence, county of conviction, victimoffender relationship and number of custody units. The variables that were found to be significant in predicting length of jail sentence were type of crime, county of conviction, length of probation and number of custody units. $^{30}$

29 No explanation was offered as to why such a lengthy departure was justified.

${ }^{30}$ It is not surprising that the number of custody units given is predictive of the length of jail sentences. Judges frequently sentenced offenders to the same number of custody units and jail days. As with custody units, Multnomah county sentenced probationers to significantly fewer jail days, with an average of 33 days, compared to an average jail sentence of 54 days from the other Oregon counties $t$ $(289)=3.56, \mathfrak{p}<.05$. Those probationers convicted of Assault III and Attempted Assault II were sentenced to serve an average of 41 days in jail, while those convicted of the more legally serious assault crimes were sentenced to serve an average of 58 days in jail $\underline{\mathbf{t}}(88)=1.96, \underline{p}=.05$. 
Use of Optional Probation

Of the 13 eligible intimate violence offenders, ten $(76.9 \%)$ were granted optional probation. ${ }^{31}$ Of the 49 nonintimate violence offenders eligible, $37(75.5 \%)$ were granted optional probation. ${ }^{32}$ All three of the intimate violence offenders who were denied optional probation were given the maximum presumptive prison sentence. In none of the cases, did the sentencing judge record a reason why optional probation was not granted. The small number of intimate violence offenders prohibited statistical comparisons of judicial discretion in the granting of optional probation to intimate and nonintimate violence offenders.

\section{Gun_Minimum_Sentence}

Firearms were used by eight (12.9\%) intimate violence offenders and $39(9.8 \%)$ nonintimate violence offenders. Two of these intimate violence offenders and eight of these nonintimate violence offenders were given gun minimum sentences. The number of offenders is too small to allow comparisons of judicial discretion in the use of gun minimum

31 Three intimate violence offenders were within the proper grid blocks for optional probation, 8-I, 8-H and 8-I, but were ineligible to receive it. One intimate violence offender was ineligible because of his supervision status at the time of the commission of the assault. Two were ineligible for optional probation because of the use of a firearm during the assault.

32 Eight nonintimate violence offenders who were ineligible for optional probation were, nonetheless, given probation sentences. Seven of them were given probation as a downward dispositional departure. The judge granted optional probation to the eighth, even though he was ineligible, due to his supervision status at the time of the assault. 
sentences between intimate and nonintimate violence offenders. ${ }^{33}$

The fact that 48 offenders used firearms and only 10 gun minimum sentences were given is surprising because Oregon law (ORS 161.610) mandates such a sentence in these cases. While the law provides the option of departure from the length of the gun minimum sentence, it does not allow discretion in its use. ${ }^{34}$

Direction and Type of Sentencing Guidelines Departure

Thirteen (18.6\%) intimate violence offenders were given sentences that departed from Oregon's sentencing guidelines. Eighty-nine $(22.4 \%)$ nonintimate violence offenders were given sentences that departed from

33 Both of the intimate violence offenders given a gun minimum sentence were convicted of Assault I. One of these offenders was sentenced to 55 months in prison, a departure from the 60 month gun minimum. He was on probation at the time of the commission of the assault. Of the seven intimate violence offenders who were not given gun minimum sentences, four were convicted of Assault II. One of them was convicted of Attempted Assault I, another of Attempted Assault II and the remaining offender for Assault III. Three were on supervision status. Three were sentenced to probation. One of these probationers was given a downward dispositional departure, as if it were the presumptive sentence type, despite the fact that the offender was under post-prison supervision at the time of the commission of the assault.

34 In several cases in which a victim was shot by the offender, the gun was not considered during the process of conviction and sentencing. For example, one offender committed a drive-by shooting at the home of a rival gang member. $\mathrm{He}$ was arrested for Attempted Assault I With A Firearm and additional charges, including Ex-Felon in Possession of A Firearm. The sentencing order read that he had plead guilty to the charge of Attempted Assault I. The order stated that the charge of Ex-Felon in Possession of A Firearm was dismissed, as was the phrase "With A Firearm," formerly part of the Attempted Assault I charge. This offender was not given a gun minimum sentence, in fact, the sentencing guidelines worksheet submitted to the OCJC stated that a gun was not involved. 
the sentencing guidelines. One (1.4\%) intimate violence offender was given an upward departure sentence and $28(7 \%)$ nonintimate violence offenders were given an upward departure sentence. Downward departures were given to $12(17.1 \%)$ intimate violence offenders and to $63(15.8 \%)$ nonintimate violence offenders (see Table 5). The small number of departures did not permit statistical analyses.

Durational departure sentences were given to $65(13.9 \%)$ offenders, overall. Eight intimate violence offenders were given sentences that were durational departures. One (1.4\%) intimate violence offender was given an upward durational departure sentence and seven (10\%) were given sentences that were downward durational departures. ${ }^{35}$ The nonintimate

35 The intimate violence offender who received an upward durational departure was a white 43-year-old male who assaulted his girlfriend. He was convicted of Assault II, had a criminal history category of $D$, and was on probation at the time of the assault. The court increased his presumptive prison sentence by 10 months, ordered him to complete alcohol and drug treatment and to undergo a mental health evaluation. Aggravating factors cited by the judge were; deliberate cruelty to victim, persistent similar offenses and other factors.

Six of the seven intimate violence offenders who were given downward durational departure were convicted and sentenced in Multnomah county. One was convicted of Assault III, three of Attempted Assault II, one of Assault II, one of Attempted Assault I and one was convicted of Assault I. Four of the intimate violence offenders were under correctional supervision at the time of the commission of the assault. Two of the offenders were white, four were African American and one was Hispanic. The mitigating factors cited were; defendant's mental capacity, other factors and offense accomplished by another. The latter factor was cited in the sentencing order of an offender who captured and restrained his former girlfriend, so that his current girlfriend could assault her. No mitigating factors were cited in the sentencing of two of the intimate violence offenders. The departure sentences were given as if the abbreviated length were the offenders' presumptive sentences. 
violence offenders given departure sentences were more equally split between upward and downward durational departures. Twenty-eight (7\%) nonintimate violence offenders received upward durational departures and $29(7.3 \%)$ received downward durational departures (see Table 5).

Dispositional departures were given to $44(9.4 \%)$ offenders, overall. Five $(7.1 \%)$ intimate violence offenders received dispositional departures and all of these were downward from prison to probation. ${ }^{36}$ Of the nonintimate violence offenders, three $(0.8 \%)$ received upward departures from probation to prison and $36(9 \%)$ received downward departures from prison to probation (see Table 5). The small number of intimate violence offenders given dispositional and durational departures prohibits statistical analyses of group differences.

${ }^{36}$ All five of the intimate violence offenders who were given probation, instead of prison, were convicted of assaulting their present or former girlfriends. The mitigating factors cited to justify these dispositional departures were; defendant's cooperation with the state, conviction free for a significant period of time and other factors. One offender, whose presumptive sentence was 41 to 45 months in prison, was sentenced to 36 months probation, drug treatment and no days in jail. His criminal history category was A and he was convicted of Assault II. The mitigating factor cited to justify the departure was "other factors." Another offender sentenced in Multnomah county, was under post-prison supervision at the time of the assault. He was convicted of Attempted Assault II and was sentenced to 36 months probation, instead of 10 to 12 months in prison. Although a gun was involved in the assault, no gun minimum sentence was given and the offender was not sentenced to any jail time or any number of custody units. No mitigating factors were cited. The judge gave this sentence as if it were derived from Oregon's sentencing guidelines. 
Table 5

Intimate and Nonintimate Violence Offenders

By Direction and Type of Guidelines Departure

\begin{tabular}{|l|c|c||}
\hline Departure & $\begin{array}{c}\text { Intimate } \\
\mathrm{N}=70\end{array}$ & $\begin{array}{c}\text { Nonintimate } \\
\mathrm{N}=398\end{array}$ \\
\hline Upward Durational & $1(7 \%)$ & $28(29 \%)$ \\
\hline Downward Durational & $7(54 \%)$ & $29(30 \%)$ \\
\hline Upward Dispositional & - & $3(3 \%)$ \\
\hline Downward Dispositional & $5(39 \%)$ & $36(38 \%)$ \\
\hline
\end{tabular}

\section{Length of Durational Departures}

Because only one intimate violence offender received an upward durational departure, the average length of upward duration departures of intimate and nonintimate violence offenders can not be meaningful compared. ${ }^{37}$ The average length of downward durational departure for intimate violence offenders sentenced to prison was 8.2 months shorter than the guidelines presumptive sentence. The average downward durational departure for nonintimate violence offenders sentenced to prison was 7.8 months shorter than the guidelines' sentence.

Since only one intimate violence offender who received a downward durational departure was sentenced to probation, the length of durational departure for intimate and nonintimate violence offenders sentenced to

37 The intimate violence offender received a sentence of 10 months longer than the sentence prescribed by the guidelines. 
probation was not compared. ${ }^{38}$

38 The intimate violence offender was sentenced to 24 months of probation, which was a downward durational departure of 12 months. The judge gave this reduced sentence as if it were a presumptive sentence derived from the guidelines. 


\section{CHAPTER VI \\ DISCUSSION}

\section{Summary of Results}

The purpose of this study was to test the hypothesis that intimate violence offenders convicted of serious assaults receive more lenient punishment than nonintimate violence offenders. Data were used to evaluate seven research hypotheses. Below, each hypothesis is listed followed by a discussion of findings.

1. Intimate violence offenders are more likely than nonintimate violence offenders to receive a sentence type of probation.

The data revealed that a nearly identical proportion of intimate and nonintimate violence offenders were sentenced to probation. This finding of no difference lends no support to the research hypothesis. However, when presumptive sentence type was taken into account, proportionately more intimate violence offenders with a presumptive sentence of prison were given probation than nonintimate violence offenders. This supporting evidence must be considered anecdotal because statistical tests could not be performed due to an inadequate number of offenders in two of the categories of comparison.

2. Intimate violence offenders receive shorter sentences than nonintimate violence offenders.

This hypothesis, if taken at face value, found support among those offenders sentenced to probation, but not among those sentenced to prison. Intimate violence offenders sentenced to probation were, indeed, given 
shorter sentences than nonintimate violence offenders. The regression analyses of probation length showed when other factors were taken into account, victim-offender relationship did not significantly influence sentence length. The average prison sentence of intimate violence offenders was shorter than nonintimate violence offenders but this difference was not statistically significant. These findings do not lend support to the assertion that intimate violence offenders receive shorter sentences than nonintimate violence offenders.

3. Intimate violence offenders are sentenced to fewer custody_units_and jail days than nonintimate violence offenders.

This hypothesis was not supported by the data. While intimate violence offenders sentenced to probation were given, on average, fewer custody units and jail days than nonintimate violence offenders, this difference was not statistically significant.

4. Eligible intimate violence offenders are more likely than eligible nonintimate violence offenders to be given optional probation, instead of prison.

Intimate and nonintimate violence offenders were granted optional probation in similar proportions thus lending no support to the research hypothesis.

5. Intimate violence offenders who used firearms during the commission of the assault are less likely than nonintimate violence offenders to receive a.gun minimum sentence.

The numbers of intimate and nonintimate violence offenders who used firearms and received gun minimum sentences were too small to 
address this hypothesis.

6. When there are departures from presumptive sentences, both downward dispositional and downward durational departures are more likely in the sentencing of intimate violence offenders than in the sentencing of nonintimate violence offenders.

The number of intimate violence offenders who received guidelines departures of any kind was very small, disallowing comparisons of the type and direction of sentencing guidelines departures.

7. Downward durational departures result in shorter sentences for intimate violence offenders than nonintimate violence offenders.

While the downward durational departures did result in shorter average prison sentences for intimate violence offenders than nonintimate violence offenders, this finding cannot support the above hypothesis because it is based on very few cases.

One of the main findings of this study is that, in felony assault cases, sentencing decisions are more likely to reflect the provisions of Oregon's sentencing guidelines than judges' views of the victim-offender relationship. In other words, sentencing guidelines and not victimoffender relationship dictate the type and duration of punishment for felony assaults in Oregon. Once intimate violence offenders are convicted of felony assault, they do not appear to receive more lenient punishment than nonintimate violence offenders. It is possible that Oregon's sentencing guidelines counteracted the influence of patriarchal values in the sentencing of intimate violence offenders. Despite the guidelines' 
possible effect on victim-offender relationship, there was evidence that other extralegal factors, i. e. supervision status and county of conviction, had some influence on sentencing. These results support other findings that extralegal factors may not be completely ruled out under sentencing guidelines (Miller, 1994; OCJC, 1994; Oregon Supreme Court Task Force, 1994; D'Alessio \& Stolzenberg, 1993).

Since the present study did not find evidence that victim-offender relationship was among the extralegal factors influencing sentencing outcomes, this finding may lend support to the conclusion that patriarchal values do not exist within the sentencing phase of the Oregon criminal justice process. However, it is also possible that effects of patriarchal values are merely minimized by the decision rules set forth under the guidelines. In order to determine the specific effects of sentencing guidelines, a similar study could be undertaken that would compare the sentencing outcomes of intimate and nonintimate violence offenders in jurisdictions with and without sentencing guidelines. If intimate violence offenders are punished more leniently in jurisdictions without guidelines and equally or less leniently in jurisdictions with guidelines, this finding would lend support to the hypothesis that the presence of guidelines mitigates the influence of patriarchal values on the severity of punishment. It is also possible that the recently increased concern over violence in the United States has made intimate violence a high priority crime, a concern 
that may reduce the influence of victim-offender relationship in sentencing decisions.

Previous research has shown that leniency toward intimate violence offenders may be shown at other phases of the criminal justice system (Cohen, 1994; Buzawa \& Buzawa, 1993; Hart, 1993; Ford, 1991; McGuire, 1991; Crowley, Sigler \& Johnson, 1990; Gondolf \& McFerron, 1989; Erez, 1986; Langan \& Innes, 1986; Lerman, 1986; Ellis, 1984; Worden \& Pollitz, 1984; McLeod, 1983; Stanko, 1982; Davis \& Smith, 1981; Brosi, 1979; Dobash \& Dobash, 1979). Police and prosecutors often decide the fate of offenders before any judicial proceedings take place. When police officers do not arrest and prosecutors do not charge intimate violence offenders for reasons other than lack of evidence, these offenders escape without punishment. Intimate violence offenders who are offered a plea bargain that downgrades a serious assault to a misdemeanor or an attempted murder to an Assault III, are afforded leniency before their cases ever reach the sentencing phase of the criminal justice process and, therefore, before sentencing guidelines come into play.

In support of other research findings (Hart, 1993; Ford, 1991; McGuire, 1991; Crowley, Sigler \& Johnson, 1990; Lerman, 1986; Ellis, 1984; McLeod, 1983; Stanko, 1982; Brosi, 1979), the present study found some evidence of possible prosecutorial downgrading of charges in intimate violence cases. Significantly more intimate than nonintimate 
violence offenders were found among those convicted of the attempted assault crimes. Attempted assaults are given seriousness rankings two levels below the rankings of the completed crimes. In some cases, when intimate violence offender were convicted of an attempted assault, it was not that the assault had not been completed. Police reports stated that victim interviews were conducted after the victim received medical treatment at a hospital. These victims had been shot, stabbed, physically beaten and run over with vehicles. In one case, a man stabbed his ex-wife with a knife. She ran from the house, bleeding, while the offender chased her with the knife. The man was arrested on a variety of charges, including attempted murder. He was convicted of Attempted Assault II, via a plea bargain, for attempting to stab her with the knife with which he had already stabbed her. Instead of spending the presumptive 21 to 22 months in prison for completed Assault II, he received a presumptive sentence of 36 months probation.

Given the findings of this study, it might be advisable to retest the theoretical hypothesis using data from those component of the criminal justice process that are afforded more discretion than the courts under sentencing guidelines. Police departments and prosecutor's offices with no or very limited policies regarding the handling of intimate violence cases may treat intimate violence offenders with more leniency than departments and offices that limit the use of discretion. Arrest and investigation 
practices of police in intimate violence cases compared to nonintimate violence cases may be examined, as well as prosecutorial charging and plea bargain decision-making. Do prosecutors offer more lenient "deals" to intimate violence offenders than to nonintimate violence offenders? For example, in some cases, intimate violence offender became nonintimate violence offenders during the plea bargaining process. One such instance involved an offender who attempted to stab his ex-girlfriend. When a male passerby came to the aid of the woman, the assailant attempted to stab him, as well. The offender was arrested for the attempted assault of both people. In exchange for a guilty plea, the prosecutor dropped all charges in connection with the attempted assault of the woman. Since prosecutors are more free from public scrutiny than police, more lenient treatment of intimate violence offenders may be found within the prosecutorial arena.

\section{Limitations}

The findings of this study are not applicable to intimate violence offenders who were convicted of any crime other than completed or attempted Assault I, II and III as the major offense or who are exempted from Oregon's sentencing guidelines. Excluding those offenders with convictions for more serious crimes than assault created a more homogeneous population, but this exclusion also disqualified some intimate violence cases. For example, one intimate violence case involved 
a man who broke down the door to the home of his ex-girlfriend (his former residence) and proceeded to assault her. On his way out, he took the television. When the case was decided, the man was convicted of Assault III and Burglary I, for the theft of the television from an occupied dwelling. Presumably, the man's primary motivation for going to the home was not to take the television, but to assault his former partner. This case had to be excluded from consideration because Burglary I has a seriousness rank of nine and Assault III has a ranking of six. The inclusion of cases with any felony assault conviction, regardless of seriousness ranking, may have produced a different picture of sentencing of intimate violence cases. ${ }^{39}$

Analyses were limited by the relatively small number of intimate violence offenders among convicted assaulters. About half of the theoretical predictions could not be tested due to the lack of sufficient data on intimate violence offenders. Future studies of intimate violence offenders among felony populations should cast a wider net, perhaps by reviewing more than one year of felony assault cases. The present study did not record the gender of the victim in nonintimate violence cases and, therefore, the impact of victim gender on the findings is unknown.

39 Including those offenders with any felony assault conviction would have also allowed the examination of the hypothesis that, in the majority of convictions for intimate violence assaults, the assault was not the most legally serious crime of conviction. It might be that criminal justice actors view the theft of property, for example, as more serious than the beating of an intimate partner. 
The difficulty in obtaining victim-offender relationship information prevented the determination of victim-offender relationship in prior criminal convictions, lesser offenses, previous arrests and the original arrest charges. This clearly limits understanding of the criminal justice processing of intimate violence cases. Criminal history information for example, cannot be used to infer other convictions for intimate violence because victim-offender relationship could only be determined for the 1993 felony assault conviction. Likewise, convictions for lesser offenses at the same time as the 1993 assault conviction could not be assumed to have involved the same victim. ${ }^{40}$ No information is provided regarding previous arrests or the nature of the charges brought against the offender at the time of the arrest that lead to the 1993 felony assault conviction. Because of the lack of arrest information and the limited nature of the prosecution data, this study cannot provide a complete picture of the criminal justice processing of intimate violence in the state of Oregon.

${ }^{40}$ Only a few cases were identified that involved a nonintimate listed as the victim of the most serious assault and an intimate listed a the victim of a less serious offense. It seemed that in most of the intimate violence cases, either the intimate was viewed as the primary victim of the violent incident, or not treated as a victim at all. For example, a woman and her husband lived in the apartment above her sister and her sister's boyfriend. One evening, the woman heard sounds of a struggle and her sister screaming. The woman's husband ran downstairs to rescue his sister-in-law from an assault. When he arrived, the man observed his sister-in-law being kicked by her boyfriend. The brother-in-law was then attacked by the boyfriend, who brutally beat the rescuer as well. As the result of a plea bargain, the assailant was convicted for the assault of the brother-in-law and not his girlfriend, despite the severe injuries caused to the woman. 


\section{REFERENCES}

Albonetti, C. A. (1991). An integration of theories to explain judicial discretion. Social Problems, 38, 247-265.

Anderson, P. R., \& Newman, D. J. (1993). Introduction to criminal justice. New York: McGraw-Hill.

Berk, R. A., \& Newton, P. J. (1985). Does arrest really deter wife battery? An effort to replicate the findings of the Minneapolis spouse abuse experiment. American Sociological Review, 50, 253-262.

Beasley, M. E., \& Thomas, D. Q. (1994). Domestic Violence as a human rights issue. In M. A. Fineman \& R. Mykitiuk (Eds.), The Public Nature of Private Violence. New York: Routledge.

Bogan, K. M. (1990). Constructing felony sentencing guidelines in an already crowded state: Oregon breaks new ground. Crime \& Delinquency, 36, 467-487.

Breslin, W. J. (1978). Police intervention in domestic confrontation. Journal of Police Science and Administration, 6, 293-301.

Brosi, K. (1979). A cross-city comparison of felony case processing. Washington, DC: INSLAW, Inc.

Brownmiller, S. (1975). Against our will: Men, women and rape. New York: Bantam Books.

Bureau of Justice Statistics (1993, March). Survey of state prison inmates, 1991. NCJ-136949. Bureau of Justice Statistics.

Buzawa, E. S., \& Buzawa, C. G. (1993). The impact of arrest on domestic violence. American Behavioral Scientist, 36, 558-574.

Carlson, B. E. (1987). Dating violence: A research review and comparison with spouse abuse. Social Casework: The Journal of Contemporary Social Work, 16-23.

Casper, J. D., Tyler, T., \& Fisher, B. (1988). Procedural justice in felony cases. Law and Society Review, 22, 483-507.

Chen, H. (1991). Dropping in and dropping out: Judicial decision-making in the disposition of felony arrests. Journal of Criminal Justice, 19, $1-17$. 
Erez, E. (1986). Intimacy, violence and the police. Human Relations, 39, 265-281.

Erez, E., \& Tontodonata, P. (1990). The effect of victim participation in sentencing on sentence outcome. Criminology, 28, 451-474.

Estrich, S. (1987). Real rape: How the legal system victimizes women who say no. Cambridge: Harvard University Press.

Fineman, M. A., \& Mykitiuk, R. (Eds.). (1994). The public nature of private violence. New York: Routledge.

Ford, D. A. (1991). Prosection as a victim power resource: A note on empowering women in violent conjugal relationships. Law \& Society Review, I, 313-334.

Friedman, L. M. (1993). Crime and punishment in American history. New York: HarperCollins.

Gelles, R. J. (1979). Family Violence. Beverly Hills: Sage.

Gelles, R. J. (1993). Constrains against family violence: How well do they work? American Behavioral Scientist, 36, 575-586.

Gondolf, E. W. \& McFerron, J. R. (1989). Handling battering men: Police action in wife abuse cases. Criminal Justice and Behavior, 16, 429. 439.

Gordon, L. (1988). Heroes of their own lives: The politics and history of family violence, Boston 1880-1960. New York: Viking.

Hart, B. (1993). Battered women and the criminal justice system. American Behavioral Scientist, 36, 624-638.

Jaffe, P., Wolfe, D. A., Telford, A., \& Austin, G. (1986). The impact of police charges in incidents of wife abuse. Journal of Family Violence, 1, 37-49.

Jolin, A. (1984). Domestic violence legislation: An impact assessment. Journal of Police Science and Administration, 2, 451-456.

Klein, D. (1982). The dark side of marriage: Battered wives and the domination of women. In N. H. Rafter \& E. A. Stanko (Eds.), Judge, Lawyer, Victim, Thief. New York: Northeastern University Press. 
Langan, P. A. (1985). Racism on trial: New evidence to explain the racial composition of prisons in the Unites States. Journal of Criminal Law and Criminology, 76, 666-683.

Langan, P. A., \& Innes, C. A. (1986). Preventing domestic violence against women: Discussion paper. Washington, DC: Bureau of Justice Statistics.

Lerman, L. G. (1986). Prosecution of wife beaters: Institutional obstacles and innovations. In M. Lystad (Ed.), Violence in the Home: Interdisciplinary Perspectives. New York: Brunner/Mazel.

Lerner, G. (1986). The creation of patriarchy. New York: Oxford University Press.

Mahoney, M. R. (1994). Victimization or oppression? Women's lives, violence, and agency. In M. A. Fineman \& R. Mykitiuk (Eds.), The Public Nature of Private Violence. New York: Routledge.

Martin, D. (1981). Battered wives: Revised, updated. Volcano, CA: Volcano Press.

Marcus, I. (1994). Reframing domestic violence: Terrorism in the home. In M. A. Fineman \& R. Mykitiuk (Eds.), The Public Nature of Private Violence. New York: Routledge.

McGuire, L. A. (1991). Prosecution of domestic violence in Iowa. Iowa Prosecuting Attorneys Training Coordinator Council, Des Moines, IA.

McLeod, M. (1983). Victim noncooperation in the prosecution of domestic assault. Criminology, 21, 395-416.

Messerschmidt, J. W. (1986). Capitalism, patriarchy, and crime: Toward a socialist feminist criminology. Totowa, NJ: Rowman and Littlefield.

Miller, J. L. (1994). A study of criminal justice discretion. Journal of Criminal Justice, 22, 107-123.

Mohr, R. M. (1990). Sentencing as a gendered process: Results of consultation. Canadian Journal of Criminology, July, 479-485.

Myers, D. G. (1989). Psychology. Holland, MI: Worth. 
Worden, R. E., \& Pollitz, A. A. (1984). Police arrests in domestic disturbances: A further look. Law and Society Review, 18, 105-119.

Yllo, K. (1988). Political and methodological debates in wife abuse research. In K. Yllo \& M. Bogard (Eds.), Feminist perspectives on wife abuse. Newbury Park: Sage.

Yllo, K. \& Bogard, M. (Eds.). (1988). Feminist perspectives on wife abuse. Newbury Park: Sage. 


\section{APPENDIX A \\ Criminal History Categories}

OAR 253-04007 CRIMINAL HISTORY CATEGORIES. The criminal history categories in the Criminal History Scale are:

Criminal

History

Category

Descriotive Criminal Yistory

A The offender's criminal history includes three or more person felonies in any combination of adult convictions or juvenile adjudications.

B The offender's criminal history includes two person felonies in any combination of adult convictions or juvenile adjudications.

C The offender's criminal history includes one adult conviction or juvenile adjudication for a person felony, and one or more adult conviction or juvenile adjudication for a non-person felony.

D The offender's criminal history includes one adult convietion or juvenile adjudication for a person felony, but no adult conviction or juvenile adjudications for a nonperson felony.

E The offender's criminal history includes four or more adult convictions for. nonperson felonies but no adult conviction or juvenile adjudication for a person. felony.

F The offender's criminal history includes two or three adult convictions for nonperson felonies but no adult conviction or juvenile adjudication for a person felony.

G The offender's criminal history includes four or more adult convictions for Class A misdemeanors: one adult conviction for a non-pesson felony, or three or more juvenile adjudications for non-person felonies, but no adult conviction or juvenie adjudication for a person felony.

H The offender's eriminal bistory includes no adult felony conviction or juvenile adjudication for a person felony, no more than two juvenile adjudications for nonperson felonies; and no more than three adult convictions for Class A misdemeanors.

I The offender's criminal history does not include any juvenile adjudication for a felony or any adult conviction for a felony or Class $A$ misdemeanor.

OAR 253-04-008 PERSON CLASS A ADULT MISDEMEANOR CONVICTIONS. Every two prior adult convictions of person Class A misdemeanors in the offender's criminal history shall be counted as one adult conviction of a person felony for criminal history purposes 


\section{APPENDIX B}

Sentencing Guidelines Grid

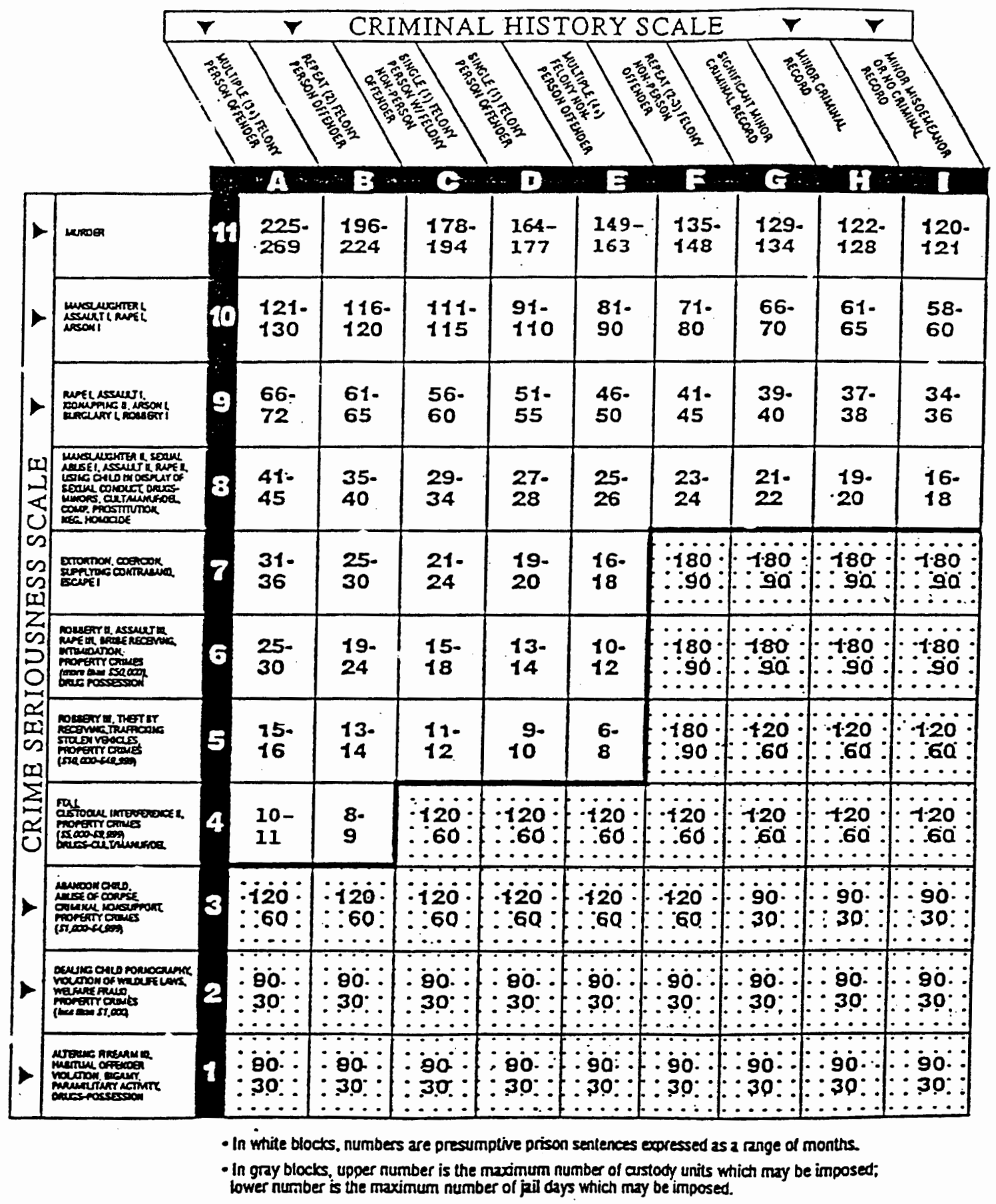

November 1. 1993 


\section{APPENDIX C \\ Mitigating and Aggravating Factors}

Mitigating and aggravating factors are cited as the statutorily relevant reasons for presumptive sentence departures. Each factor is assigned a letter and a judge may cite more than one factor.

\section{Mitigating Factors}

A. Victim involvement

B. Defendant under duress,

C. Defendant's mental capacity

D. Offense accomplished by another

E. Defendant's minor role

F. Defendant's cooperation with the state

G. Harm or loss less than typical

H. Conviction free for a significant period

I. Other

\section{Aggravating Factors}

A. Deliberate cruelty to victim

B. Victim particularly vulnerable

C. Violence toward victim or witness

D. Persistent involvement in similar offenses

E. Weapon use

F. Violation of public trust

G. Multiple victims or incidents

H. Crime part of organized operation

I. Permanent injury to person

J. Harm/loss greater than typical

K. Motivated by race, religion or sexual orientation of the victim

L. Other 


\section{APPENDIX D}

\section{Sentencing Guidelines Worksheet}

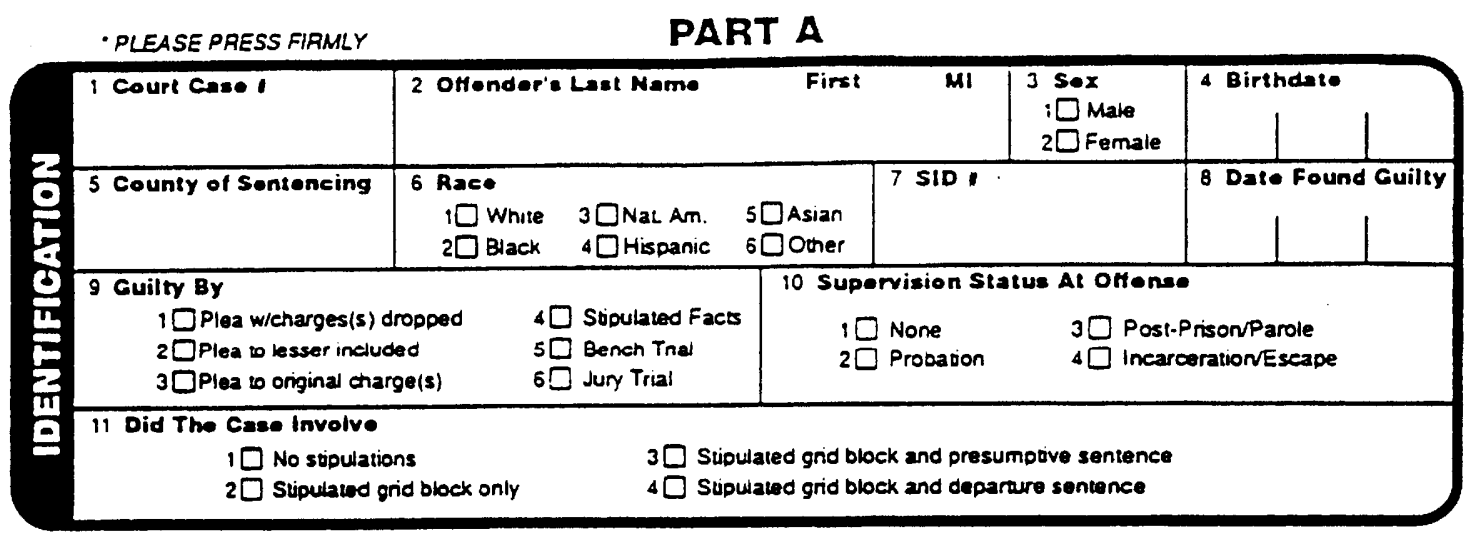

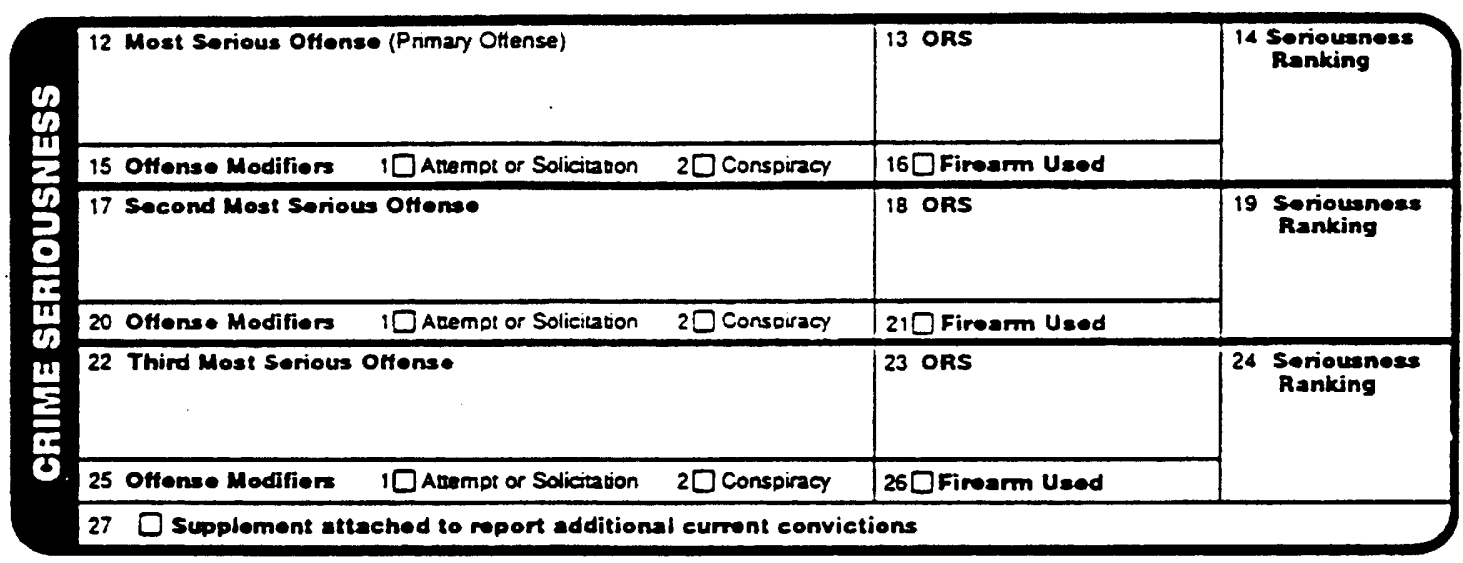

\section{CRIMINAL HISTORY CLASSIFICATION \\ $\begin{array}{llllllllll}A & B & C & D & E & F & G & H & \text { I }\end{array}$ (CIRCLE)}

29 The prosumptive guideline sentence for the primary offense is:

A prison arm of $\infty$ months and

$2 \square$ A probationary sentence

a post-prisen supervision term of montins. of months.

\section{BASE RANGE}

months to months
10 months

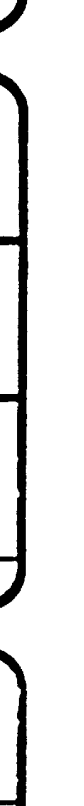




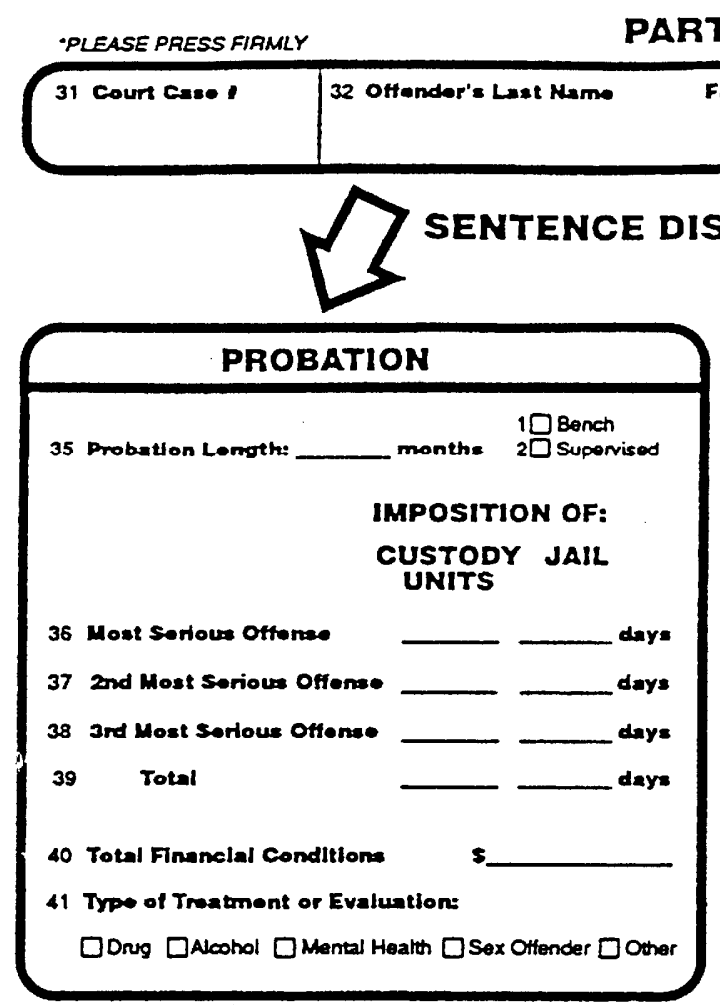

PART B

irst

\begin{tabular}{|c|c|c|c|}
33 sentencing Date & 34 Psi Ordered \\
1 & $1 \square$ Yos $2 \square$ No
\end{tabular}




\section{APPENDIX E \\ Dichotomous Variables Used in Regression Analyses}

Criminal History collapses the nine categories of criminal history to two categories. One category combines criminal history categories $\mathrm{H}$ and $\mathrm{I}$, which contains offenders with no criminal convictions or no felony convictions. The other category combines criminal history categories $\mathrm{A}$ through $G$, which may have numerous misdemeanor and felony convictions. The dichotomous criminal history variable permitted comparison of offenders with no or very limited criminal history, with those that have a more extensive criminal history.

Type of Crime combines the two less legally serious types of assault. Assault III and Attempted Assault II were combined because they both receive the same seriousness ranking. Combined, they represent the less serious category of felony assault. The other three crimes, Assault II, Attempted Assault I and Assault I are grouped together into another category to represent the more legally serious crimes.

Departure is a variable created to indicate the presence or absence of a sentencing guidelines departure.

Supervision status was created by combining both kinds of supervision statuses. One category represented offenders who were under some form of correctional supervision status at the time of the commission of the assault. The second category represents intimate offenders under no supervision status at the time of the commission of the crime.

Presumptive sentence was created by including offenders with a presumptive sentence of prison in one category and offenders with a presumptive sentence of probation in the other category.

County of Conviction was created by including the state's most populous county, Multnomah, and all other counties in another. 
APPENDIX F

Criminal History Categories of

Intimate and Nonintimate_Violence_Offenders

\begin{tabular}{|c|c|c|}
\hline Category & $\begin{array}{c}\text { Intimate } \\
\mathrm{N}=70\end{array}$ & $\begin{array}{c}\text { Nonintimate } \\
\mathrm{N}=398\end{array}$ \\
\hline $\mathrm{A}$ & 1 & 6 \\
& $1.4 \%$ & $1.5 \%$ \\
\hline B & 1 & 17 \\
& $1.4 \%$ & $4.3 \%$ \\
\hline C & 8 & 41 \\
& $11.4 \%$ & $10.3 \%$ \\
\hline D & 7 & 28 \\
& $10.0 \%$ & $7.0 \%$ \\
\hline E & 3 & 10 \\
& $4.3 \%$ & $2.5 \%$ \\
\hline F & 3 & 31 \\
& $4.3 \%$ & $7.8 \%$ \\
\hline G & 9 & 59 \\
& $12.9 \%$ & $14.8 \%$ \\
\hline H & 17 & 70 \\
& 24.3 & $17.6 \%$ \\
\hline I & 21 & 136 \\
& $30.0 \%$ & $34.2 \%$ \\
\hline
\end{tabular}




\section{APPENDIX G}

Regression Tables: Length of Probation and Prison

Length of Probation Sentence

Regression Table

\begin{tabular}{|l|c|}
\hline Independent Variable & $t$ value \\
\hline $\begin{array}{l}\text { Presumptive Probation } \\
\text { Length }\end{array}$ & $8.728^{* *}$ \\
\hline Criminal History & .263 \\
\hline Guidelines Departure & .111 \\
\hline Presumptive Sentence & .038 \\
\hline Type of Crime & -1.061 \\
\hline Intimate Relationship & -1.097 \\
\hline Supervision Status & $2.834^{* *}$ \\
\hline \multicolumn{2}{|c|}{$\mathrm{df}=7{ }^{*} \mathrm{p}<.05,{ }^{* *} \mathrm{p}<.01$} \\
\hline
\end{tabular}

Length of Prison Sentence Regression Table

\begin{tabular}{||l|c||}
\hline Independent Variable & $t$ value \\
\hline $\begin{array}{l}\text { Minimum Presumptive } \\
\text { Length }\end{array}$ & $23.177^{* *}$ \\
\hline Criminal History & -1.80 \\
\hline Guidelines Departure & .14 \\
\hline Presumptive Sentence & -.552 \\
\hline Type of Crime & .58 \\
\hline Intimate Relationship & -1.57 \\
\hline Supervision Status & .33 \\
\hline \multicolumn{2}{|c|}{$\mathrm{df}=7$}
\end{tabular}

